\title{
The Gorongoza Reserve
}

\author{
Sir Archibald James
}

The Gorongoza Game Reserve in Northern Mozambique is among the finest in the world, combining beauty of terrain with large numbers of birds and mammals in astonishing variety. About two miles from the camp is a flat treeless plain, some three miles across, flooded in the rainy season by the sluggish Pungwe river. Here some months ago I estimated well over 1000 animals of twelve species, with elephant, buffalo and wildebeest predominating, but strangely mixed.

When the reserve was established about twelve years ago a lucky mistake was made. Half a dozen pillbox-like, flat-roofed concrete houses, with outside iron staircases, were built to form the nucleus of the 'camp'. But in the rainy season, November to March, the ground proved too wet to carry vehicles, so the houses were abandoned, and were promptly taken over by the local lions, which find the staircases and flat roofs convenient. Here, and on the shady side of the houses, they will lie within feet of a car. Ken Tinley, the reserve's ecologist, knows the adult lions almost intimately, including a light-maned male which he tranquillised by darting and operated on to remove a wire snare round its neck; the scar still shows. When I was there, the 35 lions in residence split up into three prides to hunt, roughly in rotation and involving 24 hours' absence.

Shortly before the reserve was declared I was hunting in its now eastern limits. In the heavy forest there were a great many nyala (odd that Selous should have supposed them to be rare) but poaching was severe. Happily Tinley says that enough moved into the less poached areas to be now repopulating their former habitat. Accustomed to cars the game is extraordinarily tame, feeding or staring from a few yards. Recently, selecting in the heat of the afternoon a small patch of deep shade to stop in to watch a herd of elephant, we found that we were sharing it with four lionesses all within twelve feet. Three grumbled and moved off a few yards, but the biggest only raised her head before going to sleep again within three feet of the offside front wheel.

The reserve lies some 80 miles west of Beira, an attractive and growing city, 30 miles by good gravelled road from the Rhodesian border at Umtali. Well supplied with roads, it covers about 40 square miles, and is about to be enlarged by an additional 600 square miles, which will take it down to the sea and include tidal waters to protect marine life. The new area will be raaded and have two more camps. All types of terrain will then be included, from Mount Gorongoza to mangrove swamps.

The administration of reserves is under the efficient veterinary department of the Mozambique Government. The Gulbenkian Foundation (Lisbon) has built a fine laboratory and a library in the fenced perimeter of the camp - fenced because animals, from elephant and buffalo to lions and civets, roam nightly up to the gates. The accommodation in the camp could not be bettered and food and service 
are excellent. The ecologist Mr. Ken Tinley, whose wife is also a biology graduate, has an able assistant.

Last year the Government decided to create a new reserve, to be called Banyine, some hundreds of miles to the south near Laurenço Marques. It will be 80 square miles, and cover every type of terrain from kopje to mangrove, and include some species unknown or scarce in Gorongoza - giraffe, roan, sessaby and cheetah with dudong and turtles on the foreshore.

\section{The Somali Wild Ass}

The need to create a reserve for the Somali wild ass Equus asinus somalicus in Ethiopia is urgent, reports Dr Hans Klingel, who has completed his survey, described in the last Oryx, page 6. Dr Klingel has found more animals than expected, but their situation is far from secure. The major threat comes from the Afar people and their large herds of domestic animals. In the rainy season the wild asses can subsist in the desert, but in the dry season they need the water of the Awash River and the few permanent springs. It is therefore essential that the uninhabited Teo area, at present a noman's land between the Afar and Issa tribes, should be declared a wildlife reserve for the asses before either or both of these nomadic tribes decide to graze stock there, a move that may be precipitated by the building of the AwashTendaho highway now going on right through the Teo area. This might lead these nomadic people to change their migration. pattern, and the road might easily become accepted as a boundary between their grazing lands. Even in the rainy season the vegetation here is very sparse, and the wild asses could not successfully compete with stock, quite

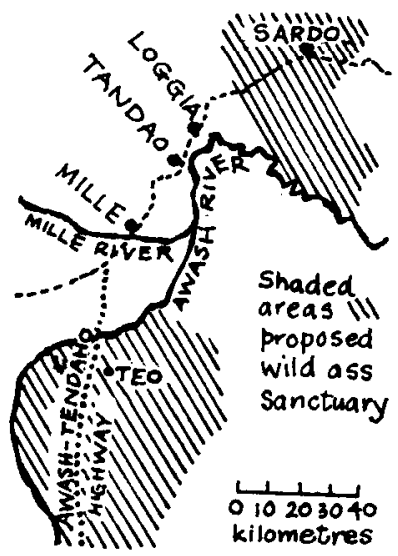
apart from being exposed to the firearms of both tribes who value their meat. The other main concentration of the wild asses, some $70 \mathrm{kms}$ to the north-east, and north of the Awash River, has to contend in addition with some hunting and, much more serious, with tourists, whose chasing of the animals in vehicles in order to get photographs is believed to be a major cause of mortality through exhaustion. Dr Klingel recommends a reserve of about 2800 square $\mathrm{kms}$ in the Teo area, with Afar game guards under an Ethiopian warden to enforce the game laws, and notices (in Amharic, English and Italian) warning visitors that chasing any wild animals by vehicles is illegal and could mean confiscation of the vehicle. 